\title{
Epiphytic yeasts from Piperaceae as biocontrol agents for foot rot of black pepper caused by Phytophthora capsici
}

\author{
DIAN SAFITRI ${ }^{1, \vartheta}$, SURYO WIYONO ${ }^{2, v v}$, BONNY POERNOMO WAHYU SOEKARNO ${ }^{2, v v \vee}$, ACHMAD $^{3, v v v \vee}$ \\ ${ }^{1}$ Doctoral Program in Phytopathology, Graduate School, Institut Pertanian Bogor. Jl. Raya Dramaga, Kampus IPB Darmaga, Bogor 16680, West \\ Java, Indonesia. Tel.: +62-251-8622642. "email: diansafitri2111@gmail.com \\ ${ }^{2}$ Departemen of Plant Protection, Faculty of Agriculture, Institut Pertanian Bogor. Jl. Kamper, Kampus IPB Darmaga, Bogor 16680, West Java, \\ Indonesia. Tel.: +62-251-8622642. "wemail: suryowi@apps.ipb.ac.id, "vwbonny@apps.ipb.ac.id \\ ${ }^{3}$ Department of Silviculture, Faculty of Forestry and Environment, Institut Pertanian Bogor. J1. Ulin, Lingkar Akademik, Kampus IPB Darmaga,

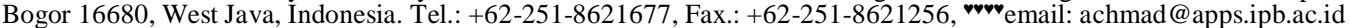

Manuscript received: 18 November 2020. Revision accepted: 23 March 2021.

\begin{abstract}
Safitri D, Wiyono S, Soekarno BPW, Achmad. 2021. Epiphytic yeasts from Piperaceae as biocontrol agents for foot rot of black pepper caused by Phytophthora capsici. Biodiversitas 22: 1895-1901. Phytophthora capsici, is a causative agent of footrot disease, is the primary pathogen in black pepper (Piper nigrum L.). Footrot disease may cause a loss of $67 \%$ black pepper production. Yeast as a biocontrol is a promising technique to control foot rot disease. This study aimed to isolate, characterize yeasts from several species of Piper and determine their effectiveness against foot rot disease. Epiphytic yeasts were isolated from fruits, stems, and leaves of Piper nigrum, $P$. retrofractum, and $P$. ornatum. The epiphytic yeasts were tested for their antagonistic activity against $P$. capsici as biocontrol agents. The antagonistic activity was observed through antibiosis mechanisms, volatile organic compound production, hyperparasitism, and the production of $\beta 1-1,3$ glucanase enzyme. A total of 48 epiphytic yeasts were isolated from Piper species. There were five isolates with high antibiosis activity in vitro, i.e. EPT23, EPT62, EPT63, EPT69, EPT70, and identified through molecular identification as Rhodotorula glutinis, Cryptococcus magnus, Filobasidium globisporum, R. mucilaginosa, H. oryzae, respectively. The selected yeast showed biocontrol activity against foot rot disease ranged from 56.7 to $80.0 \%$.
\end{abstract}

Keywords: Antibiosis, biocontrol, enzyme production, identification

\section{INTRODUCTION}

Footrot disease, caused by Phytophthora capsici, is the most destructive disease in black pepper (Piper nigrum L.). The foot rot disease is widespread in black pepper growing areas in Indonesia that cause up to $40 \%$ production loss every year. It is also one main issue in black pepperproducing countries such as India, Vietnam, and Brazil. $P$. capsici attack almost all pepper plant parts, but the most dangerous attack is on the roots and stem base (Nguyen 2015).

There has been no effective way to control foot rot disease because the pathogen can survive in the soil as a saprobe and immediately kill black pepper plants (Ginting and Maryono 2011). Resistant varieties or fungicides have not been able to prevent foot rot disease. The assembly of high-yielding and wilt-resistant varieties take a long time because black pepper is a perennial plant. The virulence of $P$. capsici which attack black pepper also varies (Wahyuno et al. 2016). On the other hand, the application of the fungicide may increase environmental pollution. Therefore, it is necessary to find effective, compatible, and sustainable disease control techniques.

Indonesia has a high diversity of microbes, and many are potential biological control agents (Meitz et al. 2010). Epiphytic yeasts can be used as biological control agents. However, its effectiveness was still low (40-46\%). Therefore, it requires further research on biological control agents that can suppress the development of $P$. capsici. The use of yeast as the biological agent is not widely known in Indonesia. Previous research was limited to certain types of yeast and was limited to post-harvest diseases. Kasfi et al. (2018) reported that Meyerozyma guilliermondii and Candida membranifaciens are potential as a biocontrol agent for grey mold disease on table grapes caused by Botrytis cinerea.

This study was conducted to isolate and identify epiphytic yeasts from several species of Piper. The epiphytic yeasts isolated from Piperaceae are expected to have the ability to suppress the development of foot rot disease in black pepper seedlings.

\section{MATERIALS AND METHODS}

The research was conducted at the Plant Mycology Laboratory and IPB Experimental Field at the Dramaga Campus of IPB University, Bogor, Indonesia from September 2018 to January 2020.

\section{Isolation and identification of Phytophthora capsici}

Phytophthora capsici was isolated following a method by (Gobena et al. 2012) with some modification. Symptomatic black pepper leaves were cut to a size of 0.5 x $0.5 \mathrm{~cm}$ and surface sterilized with $\mathrm{NaOCl} 1 \%$ and alcohol $70 \%$. The sterilized leaf pieces were grown on Corn Meal Agar (CMA) media and incubated at room temperature for 
48 hours. The growing mycelium was transferred to new media. The pure isolates were stored at room temperature for further treatment. Molecular identification was carried out by Polymerase Chain Reaction (PCR) utilized ITS1 and ITS 4 primer. Electrophoresis was performed using $1.5 \%$ w/v agarose gel (TopVision, Thermo) with 1000 bp GeneRuler marker and stained with ethidium bromide. PCR products were sent to the 1st Base for DNA sequencing (Gobena et al. 2012). The nucleotide sequences were compared with the nucleotide sequences found in the NCBI GenBank database, using the Basic Local Alignment Search Tool (BLAST).

\section{Isolation of yeast from three species of Piper}

Yeast samples were taken from three Piper species in Balumbang Jaya Village, Bogor District and Sukamulya Village, Sukabumi District, West Java, Indonesia. In each location in the same field, Piper nigrum, $P$. retrofractum, $P$. ornatum lines were selected, and for each row, several healthy plants from the Piperaceae family were taken out. The plant samples were the leaves, fruit, and stems of the plant. The isolation of yeast and stem rot pathogens was carried out at the Plant Mycology Laboratory of the Plant Protection Department of IPB IPB University, Bogor, Indonesia.

\section{Epiphytic yeast isolation}

The isolation of epiphytic yeast referred to (Kasfi et al. 2018) with some modification. The leaves, stems, and fruit of the sample were weighed as much as 10 grams separately, put into sterile distilled water, and incubated using a rotary shaker for 15 minutes at $120 \mathrm{rpm}$. The obtained yeast suspension was diluted to $10^{-5}$, and cultured on Yeast Glucose Chloramphenicol Agar (YGCA) medium, then incubated at $23-30^{\circ} \mathrm{C}$.

\section{Phytopathogenicity test}

Pathogenicity test was performed referred to (Nishad and Ahmed 2020) with some modification. The yeast isolates tested for their pathogenic properties on tobacco leaves. Epiphytic yeasts were grown on potato dextrose broth (PDB) media then incubated with a sway using a rotary shaker for 48 hours. After incubation, yeast suspension was injected using a $1 \mathrm{~mL}$ syringe on tobacco leaves. Pathogenic yeast isolates show symptoms of necrosis.

\section{Hemolysis test}

A hemolysis test was performed referred to (Suardana et al. 2014) with some modification. The Yeast isolates aged 5 days were streaked on a blood agar base medium (Oxoid CM55) and incubated for 48 hours at room temperature. Suardana et al. (2014) reported that testing that showed positive results was shown by forming a clear zone around the colony of yeast isolates, indicating that the isolate produced hemolysin toxin. Yeast isolates that do not produce hemolysin toxin will be used in further testing.

\section{Phytopathogenicity on black pepper seedlings test}

Phytopathogenicity testing on black pepper seedlings was carried out using Two-month-old seedlings of black pepper were ready for an in-vivo test (Martínez et al. 2016). Epiphytic yeasts were grown on potato dextrose broth (PDB) media then incubated with a sway using a rotary shaker for 48 hours. Black pepper seedlings are inoculated with yeast suspension by sprinkling the epiphytic yeast suspension to the black pepper plant seedlings' roots. Epiphytic yeast isolates that do not inhibit black pepper seedlings' growth will be used in further testing.

\section{The control mechanism of Phytophthora capsici in-vitro Hyperparasitism}

Hyperparasitism testing referred to (Köhl et al. 2019) with some modification. The 48-hours old culture of yeast was plated on Water Agar (WA) blocks at a $0.5 \mathrm{~cm}$ distance from the colony of $P$. capsici and incubated for five days. The yeast affinity in colonizing $P$. capsici mycelium was classified as (i) there was no attachment of yeast to the pathogenic hyphae; (ii) weak affinity $(\leq 10$ cells per hypha); (iii) moderate affinity (10-50 cells per hyphae); and (iv) strong affinity (> 50 cells per hypha).

\section{Antibiosis test}

Antibiosis mechanism was analyzed by dual culture method following the method by (Rosa et al. 2010). The antagonist yeast was inoculated in the middle of the media. $P$. capsici was inoculated on the right and left side of the antagonist yeast at the distance of $2.5 \mathrm{~cm}$. Inhibition zone was measured seven days after inoculation.

\section{Production of volatile compounds assay}

The volatile compounds analysis was performed according to the method (Huang et al. 2011) with some modification. The isolates of antagonist yeast were inoculated on the CMA medium at the bottom of the Petri dish. The isolate $P$. capsici was inoculated on the CMA media on the lid of the cup. Incubation was performed at room temperature for two days. The observations compared the growth of $P$. capsici in qualitative treatments on the CMA medium.

\section{Production of $\beta$-glucan assay}

The $\beta$-1.3-glucanase activity was performed on glucan media that contain subtract glucan, $\mathrm{Na}_{2} \mathrm{HPO}_{4} 0.130 \mathrm{~g}$, $\mathrm{KH}_{2} \mathrm{PO}_{4} 0.3 \mathrm{~g}, \mathrm{NaCl} 0,5 \mathrm{~g},(\mathrm{NH} 4)_{2} \mathrm{SO}_{4} 0.1 \mathrm{~g}, \mathrm{MgSO}_{4} .7 \mathrm{H}_{2} \mathrm{O}$ $0.014 \mathrm{~g}, \mathrm{CaCl}_{2}$ 0.01g, Pepton $0.250 \mathrm{~g}$, Yeast extract $0,1 \mathrm{~g}$, Bacto agar $5 \mathrm{~g}$, sterilized water $200 \mathrm{~mL}$. Yeast antagonist isolate was streaked on the glucan medium perpendicular to $P$. capsici and incubated at room temperature for 3-5 days. After incubation, the clear zone around the yeast indicates glucanase enzyme production (Kumala et al. 2016).

\section{In-vivo assay of epiphytic yeast against Phytophthora capsici in black pepper seedlings \\ Preparation of yeast isolates}

Selected yeasts were cultured on PDB media then incubated at $150 \mathrm{rpm}$ at room temperature for 72 hours. Black pepper seedlings were planted using sterile soil media added with compost in a ratio of $2: 1$. Two-monthold seedlings of black pepper were ready for an in-vivo test (Martínez et al. 2016). 


\section{Treatment and observation}

The treatments used in this test included: negative control (without application of yeast and fungicides), epiphytic yeast application, fungicide application. Every treatment has ten replications and ten sub-units of black pepper seeds in each replication. The epiphytic yeast was isolated from the surfaces of Piper nigrum, $P$. retrofractum, $P$. ornatum in Leaves, stem, and fruit. Epiphytic yeast inoculation was carried out by watered 10

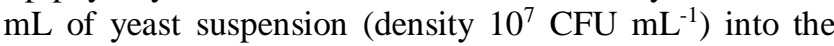
leaves, stem, and fruits of black pepper seedlings. Meanwhile, epiphytic yeast inoculation was only done by watered $10 \mathrm{~mL}$ of yeast isolate to the leaves, fruits and stem of black pepper. Fungicide application was carried out by watered the root of the plant according to the recommended dosage. Seven-day-old $P$. capsici culture was inoculated in the form of a zoospore suspension with a density of $1.1 \times 10^{5}$ spores $\mathrm{mL}^{-1}$ on the roots (Vargas et al. 2012). It was applied at ten days after epiphytic yeasts inoculation or five days before applying fungicides,

The progression of foot rot disease was observed through the following variables: latent period (LP), disease incidence (DI), disease severity (DS), infection rate (r), area under the disease progression curve (AUDPC). The latency period was calculated from the inoculation of the pathogen until the appearance of the first symptoms.

Disease incidence was estimated using the formula as follows:

$$
\mathrm{DI}=\mathrm{n} / \mathrm{N} \times 100 \%,
$$

Where: $\mathrm{n}$ : number of infected plants and $\mathrm{N}$ : number of plants observed.

Measurement of disease severity was carried out according to Cooke (1998); Bock et al. (2012) with the formula as follows :

$$
\mathrm{DS}=\left(\sum \_1^{\wedge} 3[\text { ni.vi } \rrbracket) /(\mathrm{N} . \mathrm{V}) \times 100 \%\right.
$$

Where: ni: number of infected plants on the $\mathrm{i}^{\text {th }}$ score, vi: $\mathrm{i}^{\text {th }}$ score, $\mathrm{N}$ : the number of plants observed, and $\mathrm{V}$ : the highest score in the scoring reference

The calculation of disease incidence, disease suppression, disease severity, and the progression of disease was observed one day after $P$. capsici inoculation by observing the leaf spot symptoms in each treatment. Scoring was carried out based on the method by (Ginting and Maryono 2011) (Table 1).

Table 1. Scoring of leaf spot symptoms caused by Phytophthora capsici on black pepper leaves

\begin{tabular}{ll}
\hline Score & Symptoms \\
\hline 0 & Healthy plants, fresh green leaves \\
1 & Most of the leaves turned yellow and wilt \\
2 & $\begin{array}{l}\text { Leaves remained green, but most of the leaves } \\
\text { appeared wilted }\end{array}$ \\
3 & Plants died, the stem base turned black
\end{tabular}

Identification and characterization of epiphytic yeasts

Characterization of selected epiphytic yeast morphology includes colony morphology and cell shape of yeast using a light microscope (Olympus 80i microscope). Selected yeasts were identified molecularly using specific primers NL1 and NL4. The initial stage of PCR was DNA extraction of the yeast. DNA extraction was carried out by heating the yeast at $90^{\circ} \mathrm{C}$ using a heat block (Silva et al. 2012). The next step was DNA duplication using a PCR machine with general primers NL 1 and NL 4. A total of 1 One $\mu \mathrm{L}$ of DNA solution was amplified with a reaction volume of $25 \mu \mathrm{L}$ consisting of $12.5 \mu \mathrm{L}$ master mix, one $\mu \mathrm{L}$ forward primer NL 1 (5'- GCA TAT CAA TAA GCG GAG GAA AAG - 3'), one $\mu$ L reverse primer NL 4 (5'-GGT CCG TGT TTC AAG ACG G-3') and 9.5 $\mu \mathrm{L}$ NFW. The initial denaturation cycle was carried out at $95^{\circ} \mathrm{C}$ for 90 seconds. It followed by denaturation at $95^{\circ} \mathrm{C}$ for 30 seconds, annealing $55^{\circ} \mathrm{C}$ for 30 seconds and extension at $72^{\circ} \mathrm{C}$ for 90 seconds. Steps two to four were repeated for 30 cycles and a final extension at $72^{\circ} \mathrm{C}$ for 3 minutes and $4{ }^{\circ} \mathrm{C}$ for 10 minutes. Electrophoresis was carried out in $1.5 \% \mathrm{w} / \mathrm{v}$ agarose gel (TopVision, Thermo) with 100 bp GeneRuler markers and stained with ethidium bromide. PCR products were sent to First Base for DNA sequencing. Nucleotide sequences were compared to nucleotide sequences in the NCBI GenBank database, using nucleotide BLAST (Nasanit et al. 2015).

\section{Experimental design and data analysis}

In vitro and in planta tests were conducted using a Completely Randomized Design with ten replications and ten sub-units. Tables and graphs were processed by MS. Office Excel 2010. The effect of In-vitro treatment, In planta disease progression, and treatments that significantly different were further tested by Student-Newman Keul (SNK) test at $\alpha=5 \%$ using SAS 9.1 software.

\section{RESULTS AND DISCUSSION}

\section{Exploration and pathogenicity test of epiphytic yeast}

Epiphytic yeasts were isolated from several Piper species, namely Piper nigrum, $P$. retrofractum, $P$. ornatum from two villages, i.e. Balumbang Jaya and Sukamulya, Indonesia. Forty-eight epiphytic yeasts were successfully isolated from several Piper species (Table 2). The number of epiphytic yeast isolated from the leaves was 34 isolates. Leaves contain more yeast isolates because the leaves contain nutrients favored by epiphytic yeasts. Freimoser et al. (2019) reported that the formation of yeast populations and their diversity were influenced by microclimate conditions, plant age, leaf morphology, and nutrients abundance.

The pathogenicity test of epiphytic yeast on tobacco showed that 10 yeast isolates were plant pathogens. Three epiphytic yeast isolates were pathogens to plants and mammals. Furthermore, there is no isolates epiphytic yeasts as phytopathogenicity on black pepper seedlings. Epiphytic yeasts utilize sugar, alcohol, and amino acids from the plants for their nutritional requirements (Kachalkin and Yurkov 2012). Therefore, most of the collected yeast obtained from this study was not pathogenic to plants and humans (Table 3). 
Table 2. Number of epiphytic yeast isolated from three species of Piper

\begin{tabular}{lccc}
\hline \multirow{2}{*}{ Plant's origin } & \multicolumn{3}{c}{ Number of epiphytic yeast } \\
\cline { 2 - 4 } & Leave & Fruit & Stem \\
\hline Piper nigrum & 18 & 0 & 2 \\
Piper retrofractum & 9 & 0 & 12 \\
Piper ornatum & 7 & NF & 0 \\
Number of epiphytic yeast & 34 & 0 & 14 \\
\hline
\end{tabular}

Note: ${ }^{\mathrm{N} N F}$ : No fruit

Table 3. Screening for epiphytic yeasts collected from several of species of Piper

\begin{tabular}{lcc}
\hline Testing & $\begin{array}{c}\text { The number of } \\
\text { yeast isolates } \\
\text { with a positive } \\
\text { reaction }\end{array}$ & $\begin{array}{c}\text { The number of } \\
\text { yeast isolates } \\
\text { with negative } \\
\text { reactions }\end{array}$ \\
\hline $\begin{array}{l}\text { Hypersensitivity } \\
\text { Hemolysis }\end{array}$ & 10 & 38 \\
Phytopathogenicity on & 0 & 35 \\
black pepper seedlings & & 35 \\
\hline
\end{tabular}

\section{Biocontrol mechanism of epiphytic yeast against foot rot disease}

Result of the antagonistic mechanism analysis was presented in Table 4. Antibiosis test showed two isolates grown on PDA media formed clear zones, namely isolates EPT62 and EPT63. The antibiosis test on PDB media showed five isolates did not grow. It was significantly different from control. These five antagonistic yeast isolates were able to produce volatile compounds in the range of $21.25-53.06 \%$, which could inhibit the growth of $P$. capsici on PDA media. This result is in line with the report of Di Francesco et al. (2015) that cell filtrates of Aureobasidium pullulans L1 and L8 strains were both able to inhibit Monilinia laxa conidial growth and reduce pathogen lesions on fruits.

Hyperparasitism is the antagonistic property of the yeasts. The hyperparasitic character was performed by five antagonistic yeast isolates, namely EPT23, EPT62, EPT63, EPT69, EPT70. Di Francesco et al. (2015) reported that $A$. pullulans can produce the cell wall degrading enzymes to degrading $M$. laxa conidial growth. Rhodotorula glutinis was reported to have strong hyperparasitic abilities against Botrytis conidia (Li et al. 2016). Several yeast isolates can produce protease enzymes and $\beta$ - glucanase enzymes.

\section{Morphological and molecular characteristics of} epiphytic yeasts

Microscopic observations showed that Rhodotorula mucilaginosa isolates have a size range of 3.23-5.00 x 2.30-4.50 $\mu \mathrm{m}$, whereas Hannaella oryzae isolates are of 2.20-5.40 x 4.23-11.10 $\mu \mathrm{m}$, Cryptococcus tephrensis are of 4.21-6.25 x 3.34-6.51 $\mu \mathrm{m}$, and Filobasidium globisporum are of 4.24-6.32 x 3.36-6.12 $\mu \mathrm{m}$ (Table 5). All isolates have a multipolar type, oval cell shape, and single and paired cell arrangements. Based on the cell size, it is indicated that $C$. tephrensis are more abundant than $R$. mucilaginosa isolates. Confirmation of 5 types of antagonistic yeast isolates against $P$. capsici in black pepper showed that the five isolates amplified on NL1 and NL4 primers have fragment sizes between 600-670 bp (Figure 1). The sequencing results of EPT23, EPT62, EPT63, EPT69, EPT70 isolates showed a high homology value between 91$96 \%$, which was identified as five different yeast species (Table 6)

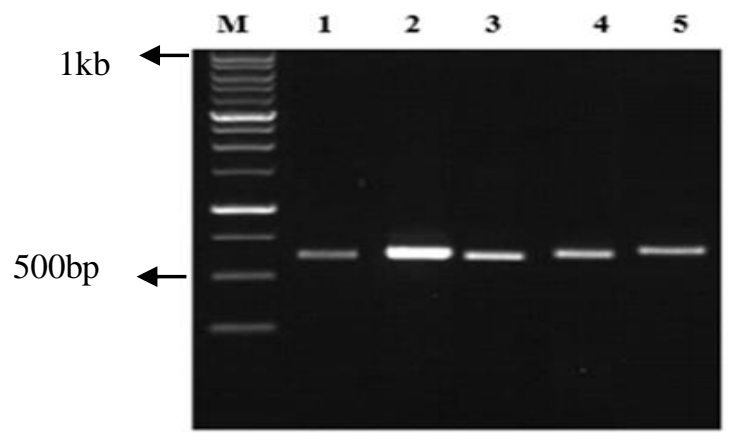

Figure 1. Visualization of the antagonistic yeast isolates on agarose gel 1,5\%M. M: Marker $1 \mathrm{~kb}$; 1-5: Samples of antagonistic yeast samples

Table 5. The cell size of selected epiphytic yeast with biocontrol properties

\begin{tabular}{clll}
\hline Isolate & \multicolumn{2}{|}{ Isolates } & \multicolumn{2}{c}{ Cell size $(\boldsymbol{\mu m})$} \\
\cline { 3 - 4 } code & & Length & Width \\
\hline EPT23 & Piper retrofractum & $3.34-4.71$ & $2.34-4.25$ \\
EPT62 & Piper retrofractum & $4.61-6.51$ & $3.24-5.31$ \\
EPT63 & Piper retrofractum & $4.24-6.32$ & $3.36-6.12$ \\
EPT69 & Piper retrofractum & $3.16-4.47$ & $2.23-4.42$ \\
EPT70 & Piper retrofractum & $2.51-5.45$ & $4.25-11.12$ \\
\hline
\end{tabular}

Table 4. Biocontrol-related characters of antagonistic yeast in inhibiting Phytophthora capsici

\begin{tabular}{|c|c|c|c|c|c|}
\hline $\begin{array}{c}\text { Isolate } \\
\text { code }\end{array}$ & 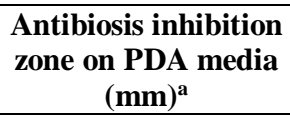 & $\begin{array}{c}\text { Decrease of biomass } \\
\text { mycelium } P \text {. capsici on } \\
\text { PDB media }(\mathrm{g})^{\mathrm{a}} \\
\end{array}$ & $\begin{array}{c}\text { Relative inhibition } \\
\text { rate of volatile } \\
\text { compound }(\%)^{\mathrm{a}} \\
\end{array}$ & $\begin{array}{c}\text { Hyperparasitism } \\
\text { (Number of affinity yeast to } \\
\text { P. capsici) (yeast colony) }\end{array}$ & $\begin{array}{c}\beta \text {-glucanase } \\
\text { production on glucan } \\
\text { media }(\mathrm{mm})^{\mathbf{a}} \\
\end{array}$ \\
\hline Control & $0.00 \mathrm{~d}$ & $6.34 \mathrm{a}$ & $0.00 \mathrm{f}$ & 0 & 0 \\
\hline EPT23 & $0.00 \mathrm{~d}$ & $0.14 b$ & $53.06 \mathrm{a}$ & $>50$ & - \\
\hline ЕРT62 & $16.06 \mathrm{~b}$ & $0.13 b$ & $28.31 \mathrm{~d}$ & $>50$ & 90 \\
\hline EPT63 & $17.49 \mathrm{a}$ & $0.15 b$ & $21.25 \mathrm{e}$ & $>50$ & - \\
\hline ЕРT69 & $0.00 \mathrm{~d}$ & $0.13 b$ & $23.71 \mathrm{e}$ & $>50$ & - \\
\hline ЕРT70 & $0.00 \mathrm{~d}$ & $0.16 \mathrm{~b}$ & $26.00 \mathrm{~d}$ & $>50$ & - \\
\hline
\end{tabular}

Note: ${ }^{a}$ Means with the same letter are not significantly different on SNK (Student-Newman-Keul) $\alpha=5 \%$, ${ }^{b}$ IR: the relative resistance levels 
Table 6. Molecular identification of epiphytic yeast isolates that potential as biocontrol

\begin{tabular}{cllccl}
\hline $\begin{array}{c}\text { Isolate } \\
\text { code }\end{array}$ & \multicolumn{1}{c}{$\begin{array}{c}\text { Accession } \\
\text { Number }\end{array}$} & $\begin{array}{c}\text { Source of isolate } \\
\text { From Genbank }\end{array}$ & $\begin{array}{c}\text { Homology } \\
(\boldsymbol{\%})\end{array}$ & $\begin{array}{c}\text { Query length } \\
(\mathbf{b p})\end{array}$ & \multicolumn{1}{c}{ Species } \\
\hline EPT23 & KJ507281.1 & Flower & 96 & 631 & R. glutinis \\
EPT62 & KJ507249.1 & Flower & 96 & 660 & Cryptococcus magnus \\
EPT63 & KY107714.1 & Plant & 96 & 662 & Filobasidium globisporum \\
EPT69 & KY109137.1 & Food & 96 & 626 & R. mucilaginosa \\
EPT70 & JQ754134.1 & Endophyte & 91 & 655 & H. oryzae \\
\hline
\end{tabular}

Table 7. The biocontrol ability of yeast antagonists against Phytophthora capsici based on in planta tests on black pepper (Piper nigrum)

\begin{tabular}{lcccccc}
\hline Isolate code & $\begin{array}{c}\text { Latent period } \\
\text { (day) }^{\mathbf{a}}\end{array}$ & $\begin{array}{c}\text { Disease } \\
\text { incidence }(\boldsymbol{\%})^{\mathbf{a}}\end{array}$ & $\begin{array}{c}\text { Disease severity } \\
(\boldsymbol{\%})^{\mathbf{a}}\end{array}$ & $\begin{array}{c}\text { Infection rate } \\
(\boldsymbol{\%})^{\mathbf{a}}\end{array}$ & $\begin{array}{c}\text { AUDPC } \\
\text { (unit) }^{\mathbf{a}}\end{array}$ & $\begin{array}{c}\text { Biocontrol } \\
\text { effectiveness }(\%)\end{array}$ \\
\hline Control & $3.10 \mathrm{~d}$ & $100.00 \mathrm{a}$ & $100.00 \mathrm{a}$ & $0.80 \mathrm{~d}$ & $468.67 \mathrm{a}$ & 0.00 \\
EPT23 & $4.20 \mathrm{abc}$ & $100.00 \mathrm{a}$ & $60.00 \mathrm{~b}$ & $1.10 \mathrm{~b}$ & $208.67 \mathrm{~b}$ & 40.00 \\
EPT62 & $4.50 \mathrm{ab}$ & $30.00 \mathrm{c}$ & $13.34 \mathrm{f}$ & $0.30 \mathrm{f}$ & $48.67 \mathrm{~g}$ & 86.66 \\
EPT63 & $4.10 \mathrm{bc}$ & $80.00 \mathrm{ab}$ & $43.33 \mathrm{~cd}$ & $0.60 \mathrm{e}$ & $148.67 \mathrm{~d}$ & 56.67 \\
EPT69 & $4.20 \mathrm{abc}$ & $100.00 \mathrm{a}$ & $53.33 \mathrm{bc}$ & $1.00 \mathrm{c}$ & $175.33 \mathrm{c}$ & 46.70 \\
EPT70 & $4.20 \mathrm{abc}$ & $50.00 \mathrm{ab}$ & $20.00 \mathrm{f}$ & $1.20 \mathrm{a}$ & $68.67 \mathrm{f}$ & 80.00 \\
Fungicide & $4.20 \mathrm{abc}$ & $30.00 \mathrm{c}$ & $10.00 \mathrm{f}$ & $0.10 \mathrm{~g}$ & $42.00 \mathrm{~g}$ & 90.00 \\
\hline
\end{tabular}

Note: ${ }^{\mathrm{a}}$ Means with the same letter are not significantly different on SNK (Student-Newman-Keul) $\alpha=5 \%$.

\section{Effectiveness of antagonistic yeast against Phytophthora capsici on black pepper seeds in-vivo}

The results showed that the black pepper seedlings treated with antagonistic yeasts have potential biological control agents against foot rot disease in black pepper seedlings. It was demonstrated by the extended incubation period, the lower disease incidence and severity in the black pepper plant treated with the yeast antagonists (Table 7).

The incubation period of the disease was longer in plant inoculated with the antagonist yeast than the control. The plant treated with antagonistic yeast showed leaves wilt symptoms on days 4 to 5 , while the control treatment showed wilt symptoms on all black pepper seedlings from day 2. The longer the incubation period of the disease, the more resistant the plant was, and vice versa. Negative control treatment has the highest disease incidence (100\%) (Table 7). Treatment of yeast antagonists can reduce the incidence of foot rot by $40-86.66 \%$, in line with the low infection rates of yeast isolates EPT23 and EPT69, ranging from $1.00 \%$ to $1.10 \%$. AUDPC values ranging from $48.7-$ 208.67 units. The higher the infection rate and AUDPC values, the higher the disease severity. A summary of some of the data from treatment was compared to control. The isolates EPT62 $(86.66 \%)$ showed a better effectiveness rate of foot rot disease development than other isolates. Wilia et al. (2012) reported that yeast Cryptococcus terreus, Candida edax, and C. albidus were able to show an $87.50 \%$ effectiveness rate against anthracnose in chilies caused by Colletotrichum acutatum.

\section{Discussion}

In this study, 48 epiphytic yeasts were isolated from the leaves, stems, and fruit of several Piper species. The number of epiphytic yeasts found in the leaf tissue (34 isolates) was higher than in the fruit and stem (Table 2). It indicated that the leaves are the most desirable habitat for yeast growth and development because of their nutrient availability. Epiphytic yeasts can interact and colonize plant tissues through stomata, hydathodes, and mechanical holes due to wounds. (Isaeva et al. 2010) reported that yeast inhabits the surface of plant tissue and can enter plant tissue through stomata, hydathodes, mechanical damages, cuticles, and epidermis.

A hypersensitivity response is a crucial property to determine the antagonist activity against plant pathogens and a mechanism of plant resistance to pathogen attack. Pathogenic infection in tobacco plants causes infected leaves to turn brown, resulting in a restricted necrotic lesion surrounding the initial infection site. Physiologically, pathogens change membrane permeability of tobacco cell walls (Balint and Kurti 2019). HR in tobacco plants showed necrosis symptoms within 24-48 hours after inoculation of yeast suspension in plant tissue. The HR test was conducted to determine whether yeast isolates were antagonistic or not against plant pathogens.

Hemolysis test on blood agar media was carried out to select antagonistic yeast isolates used as biocontrol agents. Biocontrol agents should be safe for the environment, especially mammals. Hemolysis was characterized by a clear zone surrounding the colonies on blood agar. Yeast colonies that form clear zones on blood agar are classified as $\beta$-hemolytic yeasts. Yeasts that can degrade erythrocytes are categorized into two, namely non-hemolysis or $\gamma$ hemolysis yeasts (Suardana et al. 2016). Yeast isolates that produce clear zones and potential as mammalian pathogens were not further analyzed.

In-vitro yeast selection was started by antibiosis test. It carried out on PDA and PDB inoculated with antagonist yeast and plant pathogens. Isolate EPT62, and EPT 63 performed antibiosis activity with a clear zone diameter of $16.06 \mathrm{~mm}$ and $17.49 \mathrm{~mm}$. The antibiosis test on PDB media showed that the use of yeast antagonists decreased weight of $P$. capsici mycelium. Biomass of $P$. capsici 
mycelium in antagonist yeast treatment at seven days of inoculation of $P$. capsici ranged from $0.13 \mathrm{~g}$ to $0.16 \mathrm{~g}$, significantly different from the control treatment $(6.34 \mathrm{~g})$. The inhibition of mycelium growth in antagonist yeast treatment causes by competition in nutritional uses between yeast and P. capsici on PDB media. Yeasts were better at utilizing nutrients source in starch and glucose than $P$. capsici due to its fast reproductive properties, indicated by PDB media's turbidity. Bravo et al. (2019) reported that Wickerhamomyces anomalus and S. cerevisia terrestris and Cryptococcus oeirensis reduced Botrytis cinerea conidia germination at seven days incubation by $99.67 \%$ and $71 \%$ respectively, compared to controls (without yeast treatment). This study showed that mycelium hyphae of $P$. capsici did not form a dense mycelium layer on the medium surface. There is a delay in sporulation time or no sporulation.

Another antibiosis mechanism produced by antagonistic yeasts in this study was volatile compounds (VOCs) producer. It indicated that all antagonist yeast isolates produce volatile compounds (VOCs), which could inhibit the growth of $P$. capsici, ranging from 21.25-53.06\%. EPT23 isolate produced the highest volatile compounds $(53.06 \%)$. Volatile compounds were indicated by the inhibition of $P$. capsici colony growth without physical contact between the antagonistic yeast and $P$. capsici mycelium. Contarino et al. (2019) stated metabolites in volatile compounds are an essential part of antibiosis, i.e., 3-methyl-1-butanol, 2-nonanone, and phenyl-ethyl alcohol. Yeast species of Wickerhamomyces anomalus and Kodamaea ohmeri were reported to produce VOCs (Khunnamwong et al. 2019). Di Francesco et al. (2015) reported that volatile compounds have an important role in biocontrol activity against postharvest pathogens, namely B. cinerea, Colletotrichum acutatum, Penicillium expansum, Penicillium digitatum, and Penicillium italicum.

Hyperparasitism is one of the important mechanisms in controlling foot rot disease. Five isolates of epiphytic yeast have the ability of hyperparasitism. It can be indicated by the level of affinity of the yeast to $P$. capsici mycelium. Every yeast has an affinity value that is different from other species. (Lima et al. 2013) reported that the biocontrol yeast isolates Rhodotorula glutinis LS11, Cryptococcus laurentii LS28, and Aureobasidium pullulans LS30 were tested against Botrytis cinerea and Penicillium expansum on apples. Microscopic observations showed Rhodotorula glutinis, Cryptococcus magnus, Filobasidium globisporum, $R$. mucilaginosa, $H$. oryzae caused lysis $P$. capsici cell wall indicated by the destruction of hyphae. Mode of parasitism was performed by Rhodotorula glutinis, Cryptococcus magnus, Filobasidium globisporum, $R$. mucilaginosa, $H$. oryzae. Another mechanism possessed by the antagonist yeasts in this study is the lysis ability to produce glucanase enzyme. Glucanase production is crucial in suppressing $P$. capsici hyphae. The cell wall of $P$. capsici consists of glucanase, in which cellulases are part of the $\beta$-glucan structure. Previous studies by (Lopes et al. 2015) and (Zhang et al. 2011) showed that S. cerevisiae exhibited antifungal activity against Colletotrichum acutatum secreted exoglucanases, as in the Pichia guilliermondi biocontrol isolate.

This study showed that epiphytic yeasts collected from several Piper species are potential biological control agents against foot rot disease in black pepper seeds. It is indicated by the extended disease incubation period, lower disease incidence, and disease severity in the epiphytic yeast treatments (Table 7). EPT62 bacterial isolate shows the best suppression of foot rot disease progression. Disease incidence on day 5 (end of observation) showed that control treatment had the highest disease incidence of $100 \%$. The yeast treatments of EPT23, EPT62, EPT63, EPT69, and EPT70 can reduce the incidence of footrot between $40.00 \%$ and $86.70 \%$. Huang et al. (2011) reported that yeast Wickerhamomyces anomalus could suppress $30 \%$ anthracnose in chilies caused by Colletotrichum acutatum.

Five antagonistic yeasts obtained from the stems, fruits and, leaves of Piperaceae are potential as biocontrol agents against stem rot caused by $P$. capsici. These isolates have antagonist mechanisms, namely: antibiosis, volatile compounds producer, and hyperparasitism. The five antagonistic yeast isolates, showed a homology value between $91-98 \%$ as Rhodotorula glutinis (EPT23), Cryptococcus magnus (EPT62), Filobasidium globisporum (EPT63), $R$. mucilaginosa (EPT69), and H. oryzae (EPT70). Two of the isolates $(H$. oryzae/EPT 70 and $C$. magnus/EPT 62) were able to inhibit the development of $P$. capsici in-vitro and in-vivo.

\section{REFERENCES}

Balint P and Kurti. 2019. The plant hypersensitive response: concepts, control and consequences. Mol Plant Pathol 20 (8): 1163-1178.

Bock C, Poole G, Parker P, Gottwald T . 2010. Plant disease severity estimated visually, by digital photography and image analysis, and by hyperspectral Imaging. CRC Crit Rev Plant Sci 29: 37-41.

Bravo R, Fontecilla A, Rosales I, Godoy L. 2019. Evaluation of native wine yeast as biocontrol agents against fungal pathogens related to postharvest diseases. DOI: 10.20944/preprints201909.0113.v1.

Contarino R, Brighina S, Fallico B, Cirvilleri G, Parafati L, Restuccia C. 2019. Volatile organic compounds (VOCs ) produced by biocontrol yeasts. J Food Microbiol 82: 70-74.

Di Francesco, Alessandra, Ugolini L, Lazzeri L, Mari M. 2015. Production of volatile organic compounds by Aureobasidium pullulans as a potential mechanism of action against postharvest fruit pathogens. Biol Control 81: 8-14.

Di Francesco, Roberti R, 2015. Activities of Aureobasidium pullulans cell filtrates against Monilinia laxa of peaches. Microbiol Res 181: 61-67.

Freimoser, Florian M, Mejia MPR, Tilocca B, Migheli Q. 2019. Biocontrol yeasts: mechanisms and applications. World J Microbiol Biotechnol 35 (10): 1-19.

Ginting C and Maryono T. 2011. Efikasi Trichoderma Harzianum dengan berbagai bahan organik dalam pengendalian penyakit busuk pangkal batang pada lada. J HPT Trop 11 (2): 147-156.

Gobena, Daniel, McGrath MT, Lamour K. 2012. Survival and spread of Phytophthora capsici on Long island, New York. Mycol Prog 11(3): 761-68.

Huang R, Zhang J, Yang H, Che J, Huang C. 2011. Control of postharvest Botrytis fruit rot of strawberry by volatile organic compounds of Candida intermedia. Phytopathology 101 (7): 859-869.

Isaeva O, Glushakova M, Garbuz A, Kachalkin, Yu, Chernov. 2010. Endophytic yeast fungi in plant storage tissues. Biol Bull 37 (1): 2634.

Kachalkin V, Yurkov A. 2012. Yeast communities in sphagnum phyllosphere along the temperature-moisture ecocline in the boreal forest-swamp ecosystem and description of Candida sphagnicola sp. Nov. Antonie van Leeuwenhoek, Intl J Gen Mol Microbiol 102 (1): $29-43$. 
Kasfi, Kazem, Taheri P, Jafarpour B, Tarighi S. 2018. Identification of epiphytic yeasts and bacteria with potential for biocontrol of grey mold disease on table grapes caused by Botrytis cinerea. Spanish J Agric Res 16 (1): 1-16.

Khunnamwong, Pannida, Lertwattanasakul N, Jindamorakot S Suwannarach N. 2019. Evaluation of antagonistic activity and mechanisms of endophytic yeasts against pathogenic fungi causing economic crop diseases. Mol Plant Pathol 65: 573-590.

Köhl J, Kolnaar R, Ravensberg WJ. 2019. Mode of action of microbial biological control agents against plant diseases: relevance beyond efficacy. Front Plant Sci 10: 1-19.

Kumala DT, Rachmania MN, Thennawijaya SM. 2016. Medium optimization of $\beta$-Glucanase production by Bacillus subtilis SAHA 32.6 used as biological control of oil palm pathogen. Emirates J Food Agric 28: 116-25.

Li, Boqiang, Peng H, Tian S. 2016. Attachment capability of antagonistic yeast Rhodotorula glutinis to Botrytis cinerea contributes to biocontrol efficacy. Front Microbiol 7: 1-9.

Lima J, Gondim D, Oliveira J, Oliveira F, Goncalves L, Viana F. 2013. Use of killer yeast in the management of postharvest papaya anthracnose. Postharvest Biol Technol 83: 58-64.

Lopes R, Nadjara M, Ferraz P, Silva A, Kupper K. 2015. Saccharomyces cerevisiae: A novel and efficient biological control agent for Colletotrichum acutatum during Pre-Harvest. Microbiol Res 175: $93-$ 99.

Martínez A, Valle M. Velazquez, Moctezuma H, Rodriguez R Suarez, Trujillo R, Lauzardo H. 2016. Antagonistic yeasts with potential to control Colletotrichum gloeosporioides (Penz.) Penz. \& Sacc. and Colletotrichum acutatum J.H. Simmonds on Avocado Fruits. Crop Prot 89: 101-104.
Meitz J, Linde C, Thompson A, Langenhoven S, McLeod A. 2010. Phytophthora capsici on vegetable hosts in South Africa: distribution, host range and genetic diversity. Australas. Plant Pathol 39(5): 431-39

Nasanit R, Thai A, Tantrirungkij M, Limtong S. 2015. Assessment of epiphytic yeast diversity in rice (Oryza sativa) phyllosphere in Thailand by a culture-independent approach. Antonie van leeuwenhoek, Intl J Gen Mol Microbiol 107 (6): 1475-90.

Nguyen VL. 2015. Spread of Phytophthora capsici in black pepper (Piper nigrum) in Vietnam. Engineering 7 (8): 506-513.

Nishad R, Ahmed T. 2020. Survey and identification of date palm pathogens and indigenous biocontrol agents. Plant Dis 104 (9): 24982508 .

Rosa M, Tauk S, Tornisielo, Rampazzo P, Ceccato S, Antonini S. 2010. Evaluation of the biological control by the yeast torulaspora globosa against Colletotrichum sublineolum in Sorghum. World J Microbiol Biotechno 26 (8): 1491-1502.

Suardana W, Putri P, Besung N. 2016. Isolasi dan identifikasi Escherichia coli O157: H7 pada feses sapi di Kecamatan Petang, Kabupaten Badung-Bali. Bul Vet Udayana 8 (1): 30-35.

Vargas M, Garrido F, Zapata N, Tapia M. 2012. Isolation and selection of epiphytic yeast for biocontrol of Botrytis cinerea Pers. on table grapes. Chil J Agric Res 72 (3): 332-337.

Wahyuno D, Dyah M, Ningsih S, Setijono R. 2016. Pengembangan varietas unggul lada tahan penyakit busuk pangkal batang yang disebabkan oleh Phytophthora capsici. J Penelit dan Pengemb Pertan 29 (3): 86-95.

Wilia W, Widodo, Wiyono S. 2012. Potensi khamir untuk mengendalikan penyakit antraknosa (Colletotrichum acutatum L.) pada tanaman cabai. Bioplantae 1 (4): 291-298.

Zhang D, Spadaro D, Garibaldi A, Gullino M. 2011. Potential biocontrol activity of a strain of Pichia guilliermondii against grey mold of apples and its possible modes of action. Biol Control 57 (3): 193-201. 